\title{
A POLYMERIC MULTIPLE GENE CHANGE IN HEXAPLOID WHEAT
}

\author{
O. H. FRANKEL \\ Wheat Research Institute, Department of Scientific and Industrial Research, \\ Christchurch, New Zealand
}

Received 4.i.49.

\section{DESCRIPTION AND ORIGIN OF THE MUTANT}

IN an $\mathrm{F}_{5}$ family, the progeny of an $\mathrm{F}_{4}$ plant from the cross Tuscan $\times$ White Fife made in 1928-29, two abnormalities arose. One has already been described (Frankel, I $949 a$ and $b$ ). It involves a series of inverted chromosome duplications which, though studied several generations later, have been traced back to the original $F_{5}$ family. The other was a chlorophyll defect-a variegation-in six of the twenty-five plants of this family. No such aberrant plants were found in any of the nine sister-families derived from the same $\mathrm{F}_{4}$ family, nor in any other progenies from this cross, either in the same, the preceding, or the following generations. With the exception of a few green plants which by their appearance and inheritance were identified as natural crosses, the mutant strain has remained constant since it was first found in $1933-34$.

Mutant plants have leaves with alternating green and white longitudinal sectors. Side tillers usually are poorer in chlorophyll than are the main tillers. When the tillers begin to elongate, the albinotic tissue turns green and is soon indistinguishable from normal. This process is typical of autumn sowings; but when sown in the spring, or in the winter under glass, the variegation fails to develop. Following Gustafsson (1940, and personal communication) the mutant is called striato-virescens (sv). Perhaps the first case of this kind of defect was the heterozygous variegated Vicia Faba described by Darlington (I929). Here February-sown seedlings were green, but later turned variegated and ultimately, in their upper nodes, almost white; but this process could be reversed by sowing in midsummer, and autumn-sown plants under glass were green.

The history of the cross in which the mutants occurred is summarised below ( $g=$ green, $s v=$ striato-virescens) :

\begin{tabular}{|c|c|c|}
\hline I $928-29$ & Cross & Tuscan $\times$ White Fife \\
\hline $1930-31$ & $\mathrm{~F}_{2}$ & 2800 plants \\
\hline $193^{1-32}$ & $\mathrm{~F}_{3}$ & $4^{80}$ progenies at 50 plants \\
\hline $1932-33$ & $\mathbf{F}_{4}$ & 900 progenies at 50 plants \\
\hline I $933-34$ & $F_{5}$ & $\left\{\begin{array}{l}\text { I } 599 \text { progenies at } 25 \text { plants } \\
\text { No. } 6500: 19 g 6 s v\end{array}\right.$ \\
\hline
\end{tabular}


Three of the so plants survived to maturity; their progenies were as follows :

$\begin{array}{ccc}\text { No. } 1934-35 & g & s v \\ 1078 & 0 & 20 \\ 1079 & 2 & 11 \\ 1082 & 1 & 12\end{array}$

The three green plants were doubtless natural hybrids.

Seventeen of the green plants gave progenies totalling I 440 plants ; all of these were green. One further progeny, No. r880, consisted of 37 green and 4 so plants. Of the latter, two matured and produced a total of 44 so plants. The 36 green plants tested produced a total of 12 I 2 green plants.

Thus the progeny of the $F_{5}$ plot No. 6500 shows that all plants, green as well as so, were homozygous; hence the 3 : I ratio is not due to monofactorial segregation.

Contamination can be excluded for two reasons. First, no other su-or any other chlorophyll variants-were observed on the experimental area; and secondly, the plant characters of the variants conformed to those of their sister plants and sister families. On the other hand contamination was probably responsible for the four sv plants found in the next generation in the plot No. 1880. Here also there was an absence of segregation in the progenies of the green plants; but in this case the neighbouring plot was so and hence contamination is conceivable.

\section{INHERITANCE}

(a) Crosses with unrelated normal

In I 934-35 the so mutant was crossed reciprocally with Hunters, an unrelated variety. All $F_{1}$ plants were green. In $F_{2}$, agreement with expectation on the basis of three independent recessive genes is very close (table I).

The analysis of a tri-factorial $F_{3}$ where the progeny size is limited requires special caution. The differentiation at the level of $\mathrm{P}=0.05$ of green progenies from those segregating $63:$ I would require a progeny size of $\mathrm{I} 90$ plants; and of green and those segregating $\mathrm{I} 5: \mathrm{I}$, one of 46 plants. Distinction between the segregation types requires the following family sizes: 234 plants to separate $63:$ I and I $_{5}:$ I, 50 plants to separate $I_{5}:$ I and $3: \mathrm{I}$-both at the levels of $\mathrm{P}=0.05$, giving an actual probability of $\mathrm{P}=0.025$ (Mather, 1938 ).

Levan (1944), using progenies of about 70 to 80 plants, grouped these according to observed frequencies of recessives and tested the resultant groupings of segregations against a variety of expectations. This procedure takes little account of the uncertainty of classification of segregating types in small families. Fröier ( 1946 ) in one $\mathbf{F}_{\mathbf{3}}$ eliminated altogether those families which seemed doubtful and in another grouped families by the $\chi^{2}$ test. 
The first problem which an array of segregating $\mathrm{F}_{3}$ families presents is that of defining the point of separation between segregating types. This is found in the ambiguous segregation defined by Mather (1938)

TABLE I

Segregation in $F_{2}$ of crosses striato-virescens (sv) $\times$ green $(\mathrm{g})$

\begin{tabular}{|c|c|c|c|c|c|c|c|}
\hline \multirow{2}{*}{ Season } & \multirow{2}{*}{ Parents } & \multicolumn{2}{|c|}{ Observed } & \multicolumn{2}{|c|}{ Expected } & \multirow{2}{*}{$\chi^{2}$} & \multirow{2}{*}{$\mathbf{P}$} \\
\hline & & $g$ & sv & $g$ & so & & \\
\hline I 936-37 & $\begin{array}{l}\text { Hunters } \times s v \\
s v \times \text { Hunters }\end{array}$ & $\begin{array}{r}1050 \\
1789\end{array}$ & $\begin{array}{l}16 \\
28\end{array}$ & $\begin{array}{r}63 \\
1049 \cdot 3 \\
1788 \cdot 6\end{array}$ & $\begin{array}{l}x 6 \cdot 7 \\
28 \cdot 4\end{array}$ & $\begin{array}{r}6 \\
0.0263 \\
0.0055\end{array}$ & $\begin{array}{l}\mathrm{I}<0.90 \\
<0.95\end{array}$ \\
\hline $\begin{array}{l}1943-44 \\
\text { I } 939-40 \\
\end{array}$ & $\begin{array}{l}\text { Tuscan } \times s v \\
s v \times \text { Tuscan }\end{array}$ & $\begin{array}{r}35^{80} \\
34^{\circ}\end{array}$ & $\begin{array}{r}65 \\
3\end{array}$ & $\begin{array}{r}3588 \cdot o \\
337 \cdot 6\end{array}$ & $\begin{array}{r}57 \cdot 0 \\
5 \cdot 4\end{array}$ & $\begin{array}{l}\mathrm{I} \cdot \mathrm{I} 55^{\circ} \\
\mathrm{I} \cdot 055^{2}\end{array}$ & $\begin{array}{l}<0.30 \\
>0.30\end{array}$ \\
\hline $\begin{array}{l}\text { I } 939-4^{\circ} \\
\text { I } 943-44\end{array}$ & $\begin{array}{c}\text { White Fife } \times s v \\
s v \times \text { White Fife } \\
\text { Total } \\
\text { White Fife } \times s v\end{array}$ & $\begin{array}{r}770 \\
512 \\
1282 \\
3048\end{array}$ & $\begin{array}{r}4 \\
3 \\
7 \\
19\end{array}$ & $\begin{array}{l}{ }^{255} \\
\ldots \\
1284^{\circ} \circ \\
3055^{\circ} \circ\end{array}$ & $\begin{array}{c}\mathrm{I} \\
\ldots \\
\ldots \\
5 \cdot O \\
I 2 \cdot O\end{array}$ & $\begin{array}{c}\quad 25 \\
\ldots \\
\ldots \cdot 7697 \\
4 \cdot 1289\end{array}$ & $\begin{array}{c}\text { I } \\
\quad \ldots \\
\quad \ldots \\
>0.30 \\
<0.05\end{array}$ \\
\hline $194^{8-49}$ & $s v \times$ White Fife & 4505 & 38 & $\begin{array}{r}4525 \cdot 2 \\
63 \\
4473^{\circ}\end{array}$ & $\begin{array}{l}17 \cdot 8 \\
70 \cdot 0\end{array}$ & $\begin{array}{r}23.0114 \\
6 \\
14.8575\end{array}$ & $\begin{array}{l}<0.001 \\
1<0.001\end{array}$ \\
\hline
\end{tabular}

as that ratio which will give equal $\chi^{2}$ s on both expectations. For the ratios $63: I$ and $I 5: I$ the ambiguous ratio is $30 \cdot 74: I$. In a progeny size of 234 the expectation for the ambiguous ratio is not more than $\mathrm{I}$ in 20 ; but in a progeny of only $45^{- \text {the size available }}$ for the $F_{3}$ reported here-the expectation is as high as $I$ in 5 . The separation of green from $63: 1$ requires, as stated above, igo plants and can therefore not be attempted in this material; but the differentiation of green and $\mathrm{I}_{5}: \mathrm{I}$, requiring 46 plants, and of $\mathrm{I}_{5}: \mathrm{I}$ and $3:$ i requiring 50 plants, is reasonably reliable. Moreover, to some extent misclassifications between segregation types may be expected to cancel each other out.

The grouping of $F_{3}$ progenies, using the ambiguous segregation, is given in table 2. Striato-virescens, the expected frequency of which is under six ( $c f$. Mather, 1943) is grouped with the $3:$ I class for the purpose of estimating $\chi^{2}$.

The good fit with an expectation of three recessive genes for striato-virescens supports the results obtained in $\mathrm{F}_{2}$.

\section{(b) Crosses with the parent varieties}

To test for the presence of any of the three recessive genes in the parents of the cross in which the mutant was found, homozygous striato-virescens plants were crossed with Tuscan and White Fife. 
Again all $F_{1}$ plants, in both crosses, were green. In the Tuscan cross the $F_{2}$ segregation gave a good fit with a tri-factorial expectation (table I). This was confirmed in an $F_{3}$ of $25 \mathrm{I}$ families, grouped as

TABLE 2

Frequency distribution of $F_{3}$ families in crosses striato-virescens (sv) $\times$ green (g)

\begin{tabular}{|c|c|c|c|c|c|c|}
\hline Cross & $g+63: 1$ & $15: 1$ & $3: 1$ & $s v$ & $\chi^{2}$ & $\mathbf{P}$ \\
\hline $\begin{array}{l}s v \times \text { Hunters :-- } \\
\quad \text { Observed : }\end{array}$ & 132 & 32 & 23 & I & \multirow[t]{2}{*}{0.8977} & \multirow[t]{2}{*}{$>0.3$} \\
\hline Expected . & $132 \cdot 25$ & $35 \cdot 25$ & \multicolumn{2}{|c|}{$20 \cdot 5$} & & \\
\hline $\begin{array}{c}\text { so } \times \text { Tuscan }(1944-45):- \\
\text { Observed }\end{array}$ & 184 & 40 & 25 & 2 & \multirow[t]{2}{*}{$\mathrm{I} \cdot 394^{8}$} & \multirow[t]{2}{*}{$<0.5$} \\
\hline Expected & $176 \cdot 5$ & $47^{\prime} \cdot 1$ & \multicolumn{2}{|c|}{$27 \cdot 4$} & & \\
\hline
\end{tabular}

previously indicated (table 2). In the White Fife crosses, however, there was a deficiency of $s v$. In the early crosses the best fit was with a four-gene expectation, but more recently large $\mathrm{F}_{2}$ 's gave frequencies half-way between three and four-gene expectations. Partial gametic or zygotic lethality - the most likely cause-often shows a great deal of variation in such chlorophyll defects, e.g. in barley (Gustafsson, 1938) and in flax (Levan, 1944).

\section{(c) The number of $\mathrm{sv}$ genes}

We have seen that the evidence from crosses suggests the presence of three independent recessive genes which had been acquired in the period between the cross and the $F_{5}$ in which the mutant was discovered. Is this the minimum number compatible with the evidence, or can the observed ratios be interpreted on the basis of allosyndetic pairing involving two pairs of genes?

Allosyndesis in alloploids in general and in the polyploid cereals in particular has been both inferred and observed (Winge, 1924; Darlington, I928 ; Watkins and Cory, I93I ; Philp, 1935). Its occurrence is liable to result in random chromosome and/or chromatid segregation, the consequences of which were recently reviewed by Little (1945). Both chromosome and chromatid segregation for less than three genes are excluded, the latter on the grounds of low frequencies of multivalents and both on the grounds of poor fit with observed ratios. For the $\mathbf{F}_{2}$ Hunters $\times$ striato-virescens, e.g., random chromosome segregation of two pairs of genes $(35: \mathrm{I})$ gives $\chi^{2}=6.435$ and $\mathrm{P}>\cdot \mathrm{O} \mathrm{I}$ ( $c f$. table $\mathrm{I}$ ). When the $\mathrm{F}_{3}$ is classified according to this expectation, $x^{2}=6 \cdot 38$ and $\mathrm{P}<\cdot 02(c f$. table 2$)$.

I conclude that the evidence is compatible with the assumption that the change from normal to striato-virescens involves three genes with independent inheritance. 


\section{CYTOLOGY}

(a) Parents, $F_{1}$ and $F_{2}$

(i) Univalents.-The frequencies of univalents are given in table 3. They are of an order commonly observed in Graminea (e.g. Myers, I94I) and in wheat in particular (e.g. Hollingshead, I932; Wylie, 1949). The high proportion of cells with four univalents, compared with those with two, indicates that possibly more than two bivalents are involved.

(ii) Multivalents.-The occasional occurrence of trivalents and quadrivalents is also common in wheat varieties and varietal hybrids ( $f f$. Huskins, I946; Wylie, l.c.). The frequencies of multivalent associations-one multivalent in $\mathrm{I} \cdot 6$ per cent. of cells in $F_{1}$ and $2 \cdot 4$ per cent. of cells in $F_{2}$ (table 3)-are lower than those frequently found in Triticum vulgare ( $c f$. Wylie, l.c.).

TABLE 3

Frequencies of univalents and multivalents in parents, $F_{1}$ and $F_{2}$

\begin{tabular}{|c|c|c|c|c|c|c|}
\hline & & & & Frec & cies of & \\
\hline & of plants & & $2^{1}$ & $4^{1}$ & $\mathbf{I}^{\mathrm{III}}+\mathbf{I}^{1}$ & $\mathrm{I}^{\mathrm{IV}}$ \\
\hline $\begin{array}{l}\text { Tuscan } \\
\text { White Fife } \\
\mathbf{F}_{1} . \\
\mathbf{F}_{2} .\end{array}$ & $\begin{array}{l}6 \\
7 \\
6 \\
4\end{array}$ & $\begin{array}{r}80 \\
126 \\
122 \\
81\end{array}$ & $\begin{array}{l}\cdot 038 \\
\cdot 048 \\
\cdot 139 \\
\cdot 087\end{array}$ & $\begin{array}{c}\cdots \\
\ldots \\
.024 \\
.012\end{array}$ & $\begin{array}{l}\ldots . \\
.008 \\
.008 \\
.012\end{array}$ & $\begin{array}{c}\ldots \\
\ldots \\
.008 \\
.012\end{array}$ \\
\hline
\end{tabular}

(iii) Bridge formation.-Anaphase bridges occur in both meiotic divisions ( $c f$. Frankel, I $949 b$, table 6). Bridge frequencies in anaphase I and II respectively were 0.88 per cent. and $0.8 \mathrm{I}$ per cent. in $F_{1}$ and 0.75 per cent. and 0.49 per cent. in $\mathbf{F}_{2}$. With the exception of a single second division bridge in White Fife ( $0 \cdot$ I per cent.) no bridges were found in the parents. Of all the bridges seen, only one-a first division bridge in $\mathrm{F}_{1}$ - was accompanied by a visible fragment.

\section{(b) The striato-virescens strain}

In the mutant strain, multivalents are no more common than in the parents and in the early hybrid generations. In the many thousands of cells examined, a total of ten were found with one trivalent or quadrivalent.

The striking feature in the mutant strain is the inverted duplication (referred to in the introduction), the length of which closely approximates that of the arm to which it is attached. Purely cytological features are dealt with elsewhere (Frankel, 1949a and $b$ ); in this paper only those observations which may bear on the origin of the mutant will be discussed. 
Cytological examination commenced three generations after the discovery of the mutant in an $F_{5}$ family. At this stage the inverted duplication was present throughout the mutant strain, providing evidence that the presence of the inverted duplication goes back for a minimum of three generations (Frankel, I $949 b$ ). At the time of examination no seed from either the original mutants or from their normal sister plants was available.

\section{CORRELATION OF GENETICAL AND CYTOLOGICAL EVIDENCE}

Nine of the first striato-virescens plants to be examined cytologically were crossed with one or the other of the original parents, Tuscan and White Fife. The mutant was the male parent in each case. This was rendered necessary by the fact that after cytological examination was completed, as a rule only one head was left which had to serve for both crossing and selfing, the mutant plants producing rarely more than two or three heads.

TABLE 4

Tuscan $\times$ striato-virescens, $F_{2}$ segregation from cytologically identified parent and $F_{1}$ plants

\begin{tabular}{|c|c|c|c|c|c|}
\hline \multirow{2}{*}{ Parent } & \multirow{2}{*}{$F_{1}$ no. } & \multicolumn{2}{|c|}{$\mathrm{F}_{2}:$ observed } & \multicolumn{2}{|c|}{$F_{2}:$ expected } \\
\hline & & $g$ & $s v$ & $g$ & $s v$ \\
\hline \multicolumn{6}{|c|}{ (a) $\mathrm{F}_{1}: \mathrm{N} / \mathrm{N}$} \\
\hline $\begin{array}{l}\mathrm{N} / \mathrm{N} \\
\mathrm{LD} / \mathrm{N} \\
\mathrm{LD} / \mathrm{O}\end{array}$ & $\begin{array}{l}1297 / 1-7 \\
1304 / 1-5 \\
1299 / 2-4,6,7 \\
1300 / 1,4,5 \\
1302 / 3\end{array}$ & $\begin{array}{l}850 \\
596 \\
594 \\
360 \\
119 \\
\end{array}$ & $\begin{array}{r}14 \\
9 \\
13 \\
8 \\
2 \\
\end{array}$ & $\begin{array}{l}850 \cdot 5 \\
595 \cdot 6 \\
597 \cdot 5 \\
362 \cdot 3 \\
I 19 \cdot 1\end{array}$ & $\begin{array}{r}13.5 \\
9.4 \\
9.5 \\
5.7 \\
1.9\end{array}$ \\
\hline Total & ... & 2519 & 46 & $2524 \cdot 9$ & $40 \cdot I$ \\
\hline \multicolumn{6}{|c|}{ (b) $\mathrm{F}_{\mathbf{1}}: \mathrm{LD} / \mathrm{N}$} \\
\hline $\mathrm{LD} / \mathrm{N}$ & $\begin{array}{l}1299 / 1,5 \\
1300 / 2,3,6\end{array}$ & $\begin{array}{l}232 \\
360\end{array}$ & $\begin{array}{l}6 \\
3\end{array}$ & $\begin{array}{l}234 \cdot 3 \\
357 \cdot 3\end{array}$ & $\begin{array}{l}3 \cdot 7 \\
5 \cdot 7\end{array}$ \\
\hline Total & $\ldots$ & 592 & 9 & $59 I \cdot 6$ & $9 \cdot 4$ \\
\hline \multicolumn{6}{|c|}{ (c) $\mathrm{F}_{1}: \mathrm{SD} / \mathrm{N}$} \\
\hline $\mathrm{SD} / \mathrm{N}$ & $1302 / 1,2,4$ & 252 & 9 & $256 \cdot 9$ & $4^{\cdot I}$ \\
\hline
\end{tabular}

The striato-virescens parent and the $\mathbf{F}_{1}$ plants included the following cytological types :

N/N Normal-no duplication.

$\mathrm{LD} / \mathrm{N}$ heterozygote for the original (long) duplication. 
$\mathrm{LD} / \mathrm{O} 4^{\mathrm{I}-\mathrm{chromosome}}$ plant, the univalent carrying the long duplication.

$\mathrm{SD} / \mathrm{N}$ heterozygote for short duplication (derived from the original duplication).

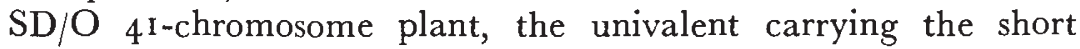
duplication.

Tables 4 and 5 give the cytological classification of parents and $\mathbf{F}_{\mathbf{1}}$ together with the resultant $\mathrm{F}_{\mathbf{2}}$ segregations.

In the Tuscan crosses (table 4), the segregation type is consistent throughout, irrespective of the presence, absence or length of the duplicated segment; the segregation for sv is not affected by its presence or absence. Whether any of the mutant genes are located in

TABLE 5

White Fife $\times$ striato-virescens. $\quad F_{2}$ segregation from cytologically identified parent and $F_{1}$ plants

\begin{tabular}{|c|c|c|c|c|c|}
\hline \multirow{2}{*}{ Parent } & \multirow{2}{*}{$F_{1}$ no. } & \multicolumn{2}{|c|}{$\mathrm{F}_{2}:$ observed } & \multicolumn{2}{|c|}{$\mathrm{F}_{2}$ : expected } \\
\hline & & $g$ & $s v$ & $g$ & $s v$ \\
\hline \multicolumn{6}{|c|}{ (a) $\mathrm{F}_{1}: \mathrm{N} / \mathrm{N}$} \\
\hline $\mathrm{N} / \mathrm{N}$ & I $306 / 1-8$ & 901 & 7 & $904 \cdot 4$ & $3 \cdot 6$ \\
\hline $\mathrm{LD} / \mathrm{N}$ & I $307 / 4,5$ & 217 & o & $216 \cdot 2$ & 0.8 \\
\hline $\mathrm{LD} / \mathrm{O}$ & $\begin{array}{l}\text { I } 308 / 6,7 \\
\text { I } 310 / 2\end{array}$ & 240 & 3 & $\begin{array}{l}24^{2} \cdot I \\
I I 9 \cdot 5\end{array}$ & $\begin{array}{l}0.9 \\
0.5\end{array}$ \\
\hline Total & $\ldots$ & I 475 & 13 & $1482 \cdot 2$ & 5.8 \\
\hline \multicolumn{6}{|c|}{ (b) $\mathrm{F}_{1}: \mathrm{LD} / \mathrm{N}$} \\
\hline $\begin{array}{l}\mathrm{LD} / \mathrm{N} \\
\mathrm{LD} / \mathrm{O}\end{array}$ & $\begin{array}{l}\text { I } 307 / \mathrm{r}-3,6 \\
\text { I } 308 / \mathrm{r}, 3,4,8 \\
\text { I } 310 / 3-5\end{array}$ & $\begin{array}{l}384 \\
484 \\
355\end{array}$ & $\begin{array}{l}\text { I } \\
\text { I } \\
\text { O }\end{array}$ & $\begin{array}{l}383 \cdot 5 \\
483 \cdot 1 \\
353 \cdot 6\end{array}$ & $\begin{array}{l}I \cdot 5 \\
I \cdot 9 \\
I \cdot 4\end{array}$ \\
\hline Total & $\ldots$ & I 223 & 2 & $1220 \cdot 2$ & $4^{\cdot 8}$ \\
\hline \multicolumn{6}{|c|}{ (c) $\mathrm{F}_{1}: \mathrm{SD} / \mathrm{N}$} \\
\hline $\begin{array}{l}\mathrm{LD} / \mathrm{N} \\
\mathrm{LD} / \mathrm{O}\end{array}$ & $\begin{array}{l}\text { I } 308 / 2,5 \\
\text { I } 310 / 1\end{array}$ & $\begin{array}{l}246 \\
107\end{array}$ & $\begin{array}{l}2 \\
2\end{array}$ & $\begin{array}{l}247^{\circ} \cdot 0 \\
108 \cdot 6\end{array}$ & $\begin{array}{l}I \cdot O \\
O \cdot 4\end{array}$ \\
\hline Total & $\cdots$ & 353 & 4 & 355.6 & $I^{*} 4$ \\
\hline
\end{tabular}

this pair at all can be ascertained by crossing a $4 \mathrm{I}$-chromosome mutant plant carrying the duplication, $\mathrm{LD} / \mathrm{O}$, , with normal $\hat{o}$, followed by selfing-or preferably backcrossing with the triple recessive-of 4 I-chromosome $F_{1}$ plants. Female gametes which lack the "duplication chromosome" are viable (male gametes are not, hence the 
reciprocal cross listed in table 4 could not be used); therefore 4 I-chromosome plants from this cross receive their only "duplication chromosome" from the normal parent, and since 40-chromosome plants are inviable the progeny will not segregate for striato-virescens if any of the genes are carried by this pair. This test is now under way. Incidentally a strain with a telocentric chromosome which lacks the arm carrying the duplication is striato-virescens; hence a mutant gene, if located in the duplication arm, must be a deletion.

When in the White Fife cross the $\mathrm{F}_{2}$ families derived from $\mathrm{N} / \mathrm{N} \mathrm{F}_{\mathbf{1}}$ plants (table $5 a$ ) are compared with those from $\mathrm{F}_{\mathbf{1}}$ plants carrying duplications (table $5^{b}$ and $c$ ), it is found that the frequency of recessives is higher in the former than in the latter. This is of doubtful significance in view of the small numbers involved, but it suggests the possibility of a connection between the inverted duplication and the differential gametic lethality suspected in this cross ( $c f$. p. ro6). It must be noted, however, that in the Tuscan cross the relationship is reversed.

\section{DISCUSSION}

I have shown in the first section that in the $\mathrm{F}_{5}$ family in which the first mutants were found, both mutant and normal plants were homozygotes. This shows (i) that the normal plants were homozygous dominant for at least one of the three sv genes, and (ii) that the gene change responsible for the occurrence of the mutants took place in all probability in the somatic phase of the mother plant. We know further that both parents of the original cross were dominant for all three genes. We must now examine how the observed gene changes can be interpreted.

\section{(a) Independent mutation}

All students of chlorophyll defects in oats and wheat stress the low frequency of chlorophyll mutants. In polyploid forms, where more than one member of a polymeric series is dominant, the chance of such mutants occurring is especially low. However, they are rare even in forms where a single gene change is readily seen, viz. in polyploids with a single pair of dominants and in diploids.

Polymeric inheritance of genes determining chlorophyll development in the polyploid cereals is well established. Direct proof comes from the many cases in which "homologous polymeric genes" (Akerman and Fröier, I94I) have been demonstrated and from the identity of gene effects where these have been ascertained (Fröier, 1946). Indirect proof comes from comparisons of frequencies of X-ray induced chlorophyll defects in diploid and polyploid-including autoploid-forms (Stadler, I929 ; Müntzing, r 94 I and 1942 ; Fröier, 1946). Generally, the higher the degree of ploidy, the rarer the occurrence of mutants. Specifically, X-ray treatment of auto-tetraploid barley yielded no mutants in $\mathrm{X}_{2}$, against an appreciable number in 
the diploid (Müntzing, I942). In alloploid forms, some X-ray induced chlorophyll mutants have been found in tetraploid wheat and hexaploid oats, all giving monofactorial segregation with normal ; but none were found in hexaploid wheat (Fröier, 1946). This indicates the rarity in wheat of non-duplicated genes, and of spontaneous mutation of polymeric genes.

Few spontaneous chlorophyll mutants have occurred in the cereals in controlled experiments. In the polyploid cereals they are confined to two well-established cases in hexaploid oats (Akerman, I929; Akerman and Fröier, I94I ; Fröier, 1946) and one in hexaploid wheat (Neatby, 1933). Each of these resulted from a single mutation step. In general, recessives are rare, otherwise chlorophyll defects would be found more frequently as segregates in varietal or specific crosses; but in hexaploid oats, varieties with one and with two recessives have been found. On the whole, however, the available evidence testifies to the stability of the chlorophyll genes in the cereals in general and of the $s v$ gen $\epsilon$ in particular, since the $s v$ type has not been previously recorded either as a segregate or as a mutant. I conclude that the possibility of a coincidence of three independent mutations is extremely remote.

\section{(b) Gene transference through autosyndesis}

Autosyndetic pairing between homologous chromosomes in different sets of an alloploid has been established in a number of species, including the polyploid cereals (cf. Darlington, 1937). Watkins and Cory (193I) found genetic evidence of autosyndesis in a pentaploid wheat cross. It plays a part in the origin of shift and its breakdown (Darlington, 1928). Philp (1935) found in a progeny of a hexaploid oat cross a chlorophyll aberration which he attributed to autosyndetic pairing. He assumed that each of the parents carried one, different, recessive belonging to a polymeric series of three. Irregular disjunction as a consequence of multivalent formation - which occurs sporadically - gave rise to a 4 I-chromosome plant with the sole dominant gene carried by the univalent. In its progeny 40 -chromosome plants are albinos, 4I-chromosome plants are green. When, however, the univalent pairs autosyndetically with one of the semi-homologous chromosomes, this causes a change in the type of segregation from I $: 6$ to $3: \mathrm{r}$. Such a change has been observed twice in $5^{6}$ progenies.

Philp assumed that two of the recessives involved were carried by the parents. In the present case, however, it is established that neither of the original parents carried any of the three genes; hence we are forced to assume (i) that one gene mutated to the recessive allele, and (ii) that the mutant gene was transferred to the two semihomologous chromosomes. This is a series of coincidences of normally rare events ; moreover it can scarcely be fitted into the space of time between the parent and $F_{5}$ generations. 
The improbability of a gradual change arises from a further consideration. It is unlikely that a condition inducing or facilitating such a process would have been terminated with the achievement of homozygosity. That it did come to an end, however, is very likely, for had it continued, $F_{1}$ plants from crosses of mutant with normal would have yielded some $\mathrm{F}_{2}$ families consisting solely of mutants.

\section{(c) Multiple mutation}

If, as we have seen, unrelated gene changes or a combination of mutation and gradual transfer are highly improbable, we are compelled to consider the possibility of related gene changes. Simultaneous gene changes in both alleles of one locus have been observed by several authors. Stubbe (1932) reported ten cases of double mutation, from the dominant to the recessive, in Antirrhinum; Müntzing (1937) one in Galeopsis from recessive to dominant ; and Mather (personal communication, $c f$. also Darlington and Mather, I 949, p. I Io) one in Antirrhinum. The specificity of multiple mutation is carried further in the present case, since both alleles of three homologues are affected.

In general, the indeterminacy of gene changes, spontaneous and induced, is as yet unchallenged: "each individual mutation remains a chance and uncontrollable event" (Muller, 1947). This mutational indeterminacy applies as a rule even where particular physiological (Muller, 1946 and 1947) or genetical (Demerec, 1937; Sturtevant, I 939; Mampell, 1943) conditions increase mutation frequencies. Yet in some specific instances the type of the resulting mutations is significantly influenced by the physiological or genetical conditions. Gustafsson (1940, 1947) found that germination onset and metabolic activity of irradiated barley seeds had specific effects on the occurrence of some types of chlorophyll mutants; this suggests a selective effect of environmental factors with regard to the nature, or at least the frequency, of mutant types. Yet the resultant mutants, though related in type, were genetically diverse. As in other mutation experiments in barley or in maize, the induced mutants were neither identical nor allelic.

Genetically controlled specificity of gene changes in Drosophila has been reported by Mampell (1945, 1946). A recessive mutator is responsible, in the presence of a Y-chromosome, for the production of a cytoplasmically transmitted mutator substance which induces predominantly mutants of the Minute type; but here again, while there is a degree of specificity of type, there is a large measure of genetic diversity among mutants.

In the changes to striato-virescens the specificity of gene change goes farther. lt is an assumption, derived from the concept of polyploidy, that members of a polymeric series are identical or closely similar not only in their effects but in their constitution. Control of 
such gene changes is therefore not only phenotypically or physiologically, but genetically specific.

That the duplication which was found in this mutant strain was in no way connected with the mutational process, that the joint appearance of the two phenomena in fact is a coincidence, is possible but hardly likely. It is far more probable that one is the consequence of the other; that the unbalance caused by the cytological change destabilised elements of heredity.

\section{(d) Polyploidy and mutation}

Polyploids do not provide suitable material for a critical study of spontaneous mutation. The precision which is obtainable in diploids (cf. e.g. Stadler, 1946, on spontaneous mutation in maize) is barred by the multiplicity of chromosomes and genes. In one respect, however, the observations reported in this paper permit definite conclusions. It is commonly assumed (e.g. Huskins, I 94I ; Fröier, I946) that in polymeric series, mutations have been accumulated over long periods of time, so that the occurrence of mutants in the various homologues may be taken as an indication of the age of a polyploid (Huskins, l.c.). The origin of striato-virescens, whatever be its cause, shows that this is not of necessity the case. Whilst there is no direct evidence that the genes involved are "homologous polymeric genes," such evidence is equally lacking in all other cases where polymeric series have been inferred. The conclusion is justified that in some circumstances parallel changes may occur, affecting more than one, and in fact all members of a polymeric series, thus breaking down the relative immunity of polyploids to the consequences of recessive mutation.

\section{SUMMARY}

I. A chlorophyll defect, named striato-virescens, which was found in an $\mathrm{F}_{5}$ family of a varietal cross in Triticum vulgare, differed from both parents in three polymeric genes with independent inheritance.

2. The occurrence of the mutant coincides with that of a large inverted chromosome duplication.

3. The origin of the mutant from independent mutation in three genes, or from a single mutation transferred autosyndetically, is considered highly improbable.

4. It remains to accept the fact that a multiple mutation occurred, probably in the somatic phase. It seems that its association with the chromosome duplication is not a mere coincidence; the duplication may be interpreted as a possible "destabiliser" of heredity.

5. The occurrence of the mutant-whatever its mode of originshows that recessive polymeric series may evolve suddenly, and hence not necessarily by individual steps over long spaces of time. 


\section{REFERENCES}

AKERMAN, A. I929.

Letalfaktorer hos havre och vete.

Beretning Nord. Jordbruksforskeres Forenings IV. Kongres, 594-604.

AKERMAN, A., AND FRÖIER, K. I94I.

Studien über eine spontane chlorina-mutation in Avena sativa.

Hereditas, 27, 371-404.

DARLINGTON, C. D. 1928.

Studies in Prunus I and II.

7. Genet., 19, 2 1 3-256.

DARLINGTON, G. D. Ig29.

Variegation and albinism in Vicia Faba.

7. Genet., 21, I6 I-1 68 .

DARLINGTON, C. D. 1937 .

Recent Advances in Cytology. 2nd ed. London.

DARLINGTON, C. D., AND MATHER, K. I 949 .

Elements of Genetics. London.

DEMEREC, M. I 937 .

Frequency of spontaneous mutations in certain stocks of Drosophila melanogaster.

Genetics, 22, 469-478.

FRANKEL, O. H. 1949 .

A self-propagating structural change in Triticum. I. Duplication and crossingover.

Heredity, 3, 163-194.

FRANKEL, O. H. I $949 b$.

A self-propagating structural change in Triticum. II. The reproductive cycle.

Heredity, 3, 293-3 18.

FRÖIER, K. I946.

Genetical studies on the chlorophyll apparatus in oats and wheat.

Hereditas, 32, 297-406.

GUSTAFSSON, A. 1938 .

Studies on the genetic basis of chlorophyll formation and the mechanism of induced mutating.

Hereditas, 24, 33-93.

GUSTAFSSON, A. I 940 .

The mutation system of the chlorophyll apparatus.

Lunds Univ. Arsskrift N.F. 2, 36/I I, I-40.

GUSTAFSSON, A. I 947 .

Mutations in agricultural plants.

Hereditas, 33, I-1 00 .

HOLLINGSHEAD, L. I 1932.

The occurrence of unpaired chromosomes in hybrids between varieties of Triticum vulgare.

Cytologia, 3, I I 9-1 41.

HUSkINs, c. L. I 94 I.

Polyploidy and mutations.

Amer. Nat., 75, 329-344. 
HUSKINS, C. L. 1946 .

Fatuoid, speltoid and related mutations of oats and wheat.

Bot. Rev., 12, 457-5 I4.

LEVAN, A. I 944 .

Experimentally induced chlorophyll mutants in flax.

Hereditas, 30, 225-230.

LITTLE, T. M. $\quad$ I 945 .

Gene segregation in autotetraploids.

Bot. Rev., II, 6o-85.

MAMPELL, K. 1943.

High mutation frequency in Drosophila pseudoobscura, Race B.

P.N.A.S., 29, 137-144.

MAMPELL, K. $\quad$ I 945 .

Analysis of a mutator.

Genetics, 3o, 496-505.

MAMPELL, K. 1946.

Genic and nongenic transmission of mutator activity.

Genetics, 3I, 589-597.

MATHER, K. 1938.

The Measurement of Linkage. London.

MATHER, K. 1943.

Statistical Analysis in Biology. London.

MULLER, H. J. 1946.

Physiological effects on "spontaneous" mutation rate in Drosophila.

Genetics, 3I, 225.

MULLER, H. J. $\quad$ I 947 .

Pilgrim Trust Lecture. The gene.

P.R.S., B, $134,1-37$.

MÜNTZING, A. 1937.

Multiple alleles and polymeric factors in Galeopsis.

Hereditas, 23, 37 I-400.

MÜNTZING, A. 1941 .

Differential response to X-ray treatment of diploid and tetraploid barley.

Kungl. Fysiogr. Sallskapets Lund Förhand. 1 I $/ 6$.

MÜNTZING, A. 1942 .

Frequency of induced chlorophyll mutations in diploid and tetraploid barley.

Hereditas, 28, 21 7-221.

MYERS, W. M. I 94 I.

Variations in chromosomal behaviour during meiosis among plants of Lolium perenne $L$.

Cytologia, II, 388-406.

NEATBY, K. W. 1933.

A chlorophyll mutation in wheat.

F. Hered., 24, 159-162.

PHILP, J. 1935 .

Aberrant albinism in polyploid oats.

7. Genet., 30, 267-302. 
STADLER, L. J. I929.

Chromosome number and the mutation rate in Avena and Triticum.

P.N.A.S., ${ }_{15}, 876-88$ r.

STADLER, L. J. 194.6.

Spontaneous mutation at the $\mathrm{R}$ locus in maize. I. The aleurone colour and plant colour effects.

Genetics, 31, 377-394.

STUBBe, H. $\quad 193^{2}$.

Untersuchungen über experimentelle Auslösung von Mutationen bei Antirrhinum majus. III.

Z.I.A.V., 6o, 474-513.

STURTEVANT, A. H. 1939 .

High mutation frequency induced by hybridisation.

P.N.A.S., 25, 308-310.

WATKINS, A. E., AND CORY, F. M. I93

Genetical and cytological studies in wheat. V.

7. Genet., 25, 55-90.

WINGE, ö. 1924 .

Zytologische Untersuchungen über Speltoide und andere mutantenähnliche Aberranten beim Weizen.

Hereditas, 5, 241-286.

WYLIL, A. P. $\quad$ I 949.

Meiotic irregularities in the wheat variety " Hilgendorf."

N.Z. F. Sci. and Tech. (In the press). 